\title{
Phytoremediation of soils contaminated with heavy metals
}

\begin{abstract}
Several studies have demonstrated that certain particular plants increase biodegradation of a number of exogenous organic molecules in contaminated soils. However, information on mechanisms, stages and the role of plants, direct or even indirect, in transforming such compounds is scarce. The objective of this work is to put on view phytoremediation as a technological helpful alternative for cleaning contaminated soils. General mechanisms and particular stages that plants use, as well as the complex interactions plants-native microorganisms-xenobiotics in the soil are reviewed. This knowledge will allow proposing solutions to problems of contamination and eventually recovering sites and soils.
\end{abstract}

Keywords: remediation, phytodegradation, xenobiotics, phytoextraction
Volume 2 Issue 4 - 2018

\author{
Prieto Méndez J,' Acevedo Sandoval OA,' \\ Prieto García F, ${ }^{2}$ Nallely Trejo González ${ }^{3}$ \\ 'Institute of Agricultural Sciences, Autonomous University of the \\ State of Hidalgo, Mexico \\ ${ }^{2}$ Chemistry Academic Area, Autonomous University of the State \\ of Hidalgo, Mexico \\ ${ }^{3} \mathrm{PhD}$ program in environmental sciences, Autonomous \\ University of the State of Hidalgo, Mexico
}

\begin{abstract}
Correspondence: Prieto García F, Chemistry Academic Area, Autonomous University of the State of Hidalgo, Highway Pachuca, Tulancingo, Carboneras, Mineral de la Reforma Hidalgo, Pachuca Hidalgo, Mexico, Email prietog@uaeh.edu.mx
\end{abstract}

Received: July 19, 2018 | Published: August 09, 2018

\section{Introduction}

The generation, distribution and accidental spills of different xenobiotic organic molecules (herbicides, insecticides, miticides and hydrocarbons, among others) have caused environmental degradation directly or indirectly accumulate in soil, water and air. Generally speaking, one can say that the rate of accumulation is greater than the capacity of the planet to remove these xenobiotic organic compounds. ${ }^{1}$ Hence the interest arises for collaborating with nature to reverse the effect of pollutants on ecosystems. ${ }^{2}$ One of the concepts that requires special attention is biodegradation, which refers to the natural process by which bacteria or other living organisms alter and convert organic molecules into less toxic substances such as fatty acids and $\mathrm{CO}_{2}$. Some recent examples are: the biodegradation of phenanthrene by roots of oats and native communities of soil $;^{3}$ biodegradation of pyrene by Festuca arundinacea L. and Panicum virgatum L., where the carbon was marked to observe carbon transformation, distribution and fate of the contaminant was used. Furthermore, bioremediation refers to the chemical transformation of contaminants by using microorganisms that meet their nutritional requirements and energy contributing to detoxification or mineralization environment by co-metabolism. ${ }^{4}$

\section{Heavy metals in soil-pollution}

The term "heavy metal" refers to those metals of the periodic tables whose specific weight is greater than $5 \mathrm{~g} . \mathrm{cm}^{3}$ or have an atomic number above 20 , generally excluding alkali and alkaline earth elements. ${ }^{5}$ The term is somewhat imprecise when taking into account the particular properties ionic physicochemical elements, properties that define the composite ability and biological properties. We used other terms such as "toxic metal" or "trace element", none of them refers to the same elements, resulting equally unsatisfactory.

In any case, according to Tiller, 5 it seems that the term "heavy metal" can be used in a globalizing way to refer to those metals classified as environmental pollutants. The metalloids, meanwhile, have characteristics intermediate between metals and non-metals according to their binding properties and ionization. Non-metals such as $\mathrm{As}, \mathrm{Se}$ or $\mathrm{Sb}$ may also be important environmental pollutants. ${ }^{6}$ Among the heavy metals there are essential and non-essential elements, for living of organisms, although the boundary between these two groups is not clearly defined and the list of biologically important elements increases with time. They are essential elements Generally Known as $\mathrm{Fe}, \mathrm{Mn}, \mathrm{Zn}, \mathrm{Cu}$, $\mathrm{Co}$ and $\mathrm{Mo}$, as $\mathrm{Ni}$ and $\mathrm{Cr}$ beneficial elements, and They are essential elements Generally Known as to $\mathrm{Fe}, \mathrm{Mn}, \mathrm{Zn}, \mathrm{Cu}, \mathrm{Co}$ and $\mathrm{Mo}$; $\mathrm{Ni}$ and $\mathrm{Cr}$ as beneficial elements, and $\mathrm{It}$ is Considered don not have a biological function $\mathrm{Cd}, \mathrm{Hg}, \mathrm{Pb}$ and As and As. ${ }^{78}$ Heavy metals, essential or not, can become toxic when their contribution is excessive and adversely affect the growth and reproduction of organisms, even cause death. The increase of heavy metals in soil also inhibits microbial enzyme activity and reduces the diversity of populations of flora and fauna, causing infertility and increasing erosion. The transfer of metals to man can occur through the ground (inhalation and ingestion of dust), food, water, air or skin (result of dermal absorption of contaminants from soil and water). ${ }^{9}$ Toxicological effects of metals to humans, particularly of $\mathrm{Cd}, \mathrm{Zn}, \mathrm{Hg}$ and $\mathrm{Pb}$ and as the Ace, which represent some of the most dangerous, have been well documented and there are references where you can get information about this., ${ }^{8,10-12}$

All soils have heavy metals as a result of geological processes and edaphogenetic. The natural content of existing chemical elements in soil is called local geochemical fund (GF) or fonds level, ${ }^{13}$ and represents an ideal situation that should be known to determine the contamination by the presence of amounts of metals unusually high. ${ }^{14}$ The determination of GF in soils is not an easy task, and its value varies geographically mainly based on the geological material. ${ }^{10}$ Generally igneous and metamorphic rocks, which occupy $95 \%$ of the earth's crust, ${ }^{15}$ have high amounts of $\mathrm{Mn}, \mathrm{Cr}, \mathrm{Co}, \mathrm{Ni}, \mathrm{Cu}$ and $\mathrm{Zn}$, and represent an important natural source of heavy metals into soil. ${ }^{13}$ The natural concentration of metals in soils derived from serpentinized ultra basic rocks, for example, becomes toxic to animals and plants as a result of the high content of heavy metals from the bedrock from which they derive. There are many references that define the typical ranges of heavy metals in the various rocks and reveal the wide variability. There are many references that define the typical ranges of heavy metals in the various rocks and reveal the wide variability (Table 1). ${ }^{13,16-18}$ 
Table I Typical ranges of concentrations of trace metals in the most abundant rock types $\left(\mathrm{mg} \cdot \mathrm{kg}^{-1}\right)^{13}$

\begin{tabular}{lllllll}
\hline \multicolumn{3}{l}{ Volcanic rocks } & \multicolumn{5}{l}{ Sedimentary rocks } \\
\hline & Ultrabasic & Basic & Granites & Limestone & Sandstone & Shale \\
\hline $\mathrm{Cd}$ & 0.12 & $0.13-0.20$ & $0.09-0.20$ & $0.028-0.10$ & 0.05 & 0.2 \\
$\mathrm{Co}$ & $110-150$ & $35-50$ & $\mathrm{I}$ & $0.1-4.0$ & 0.3 & $19-20$ \\
$\mathrm{Cr}$ & $2000-2980$ & 200 & 4 & $11-$ Oct & 35 & $90-100$ \\
$\mathrm{Cu}$ & Oct-42 & $90-100$ & $13-$ Oct & $5.5-15$ & 30 & $39-50$ \\
$\mathrm{Hg}$ & 0.004 & $0.01-0.08$ & 0.08 & $0.05-0.16$ & $0.03-0.29$ & $0.18-0.5$ \\
$\mathrm{Mn}$ & $1040-1300$ & $1500-2200$ & $400-500$ & $620-1100$ & Apr-60 & 850 \\
$\mathrm{Ni}$ & 2000 & 150 & 0.5 & $12-\mathrm{Jul}$ & $9-\mathrm{Feb}$ & $68-70$ \\
$\mathrm{~Pb}$ & $0.1-14$ & $5-\mathrm{Mar}$ & $20-24$ & $5.7-7$ & $10-A u g$ & $20-23$ \\
$\mathrm{Sn}$ & 0.5 & $\mathrm{I}-1.5$ & $3-3.5$ & $0.5-4$ & 0.5 & $6-\mathrm{Apr}$ \\
$\mathrm{Zn}$ & $50-58$ & 100 & $40-52$ & $20-25$ & $16-30$ & $100-120$ \\
\hline
\end{tabular}

Pollution of soils derived from an Increase of metal content often varies or exceeds the content in the FG. ${ }^{19}$ Until recent years, the consideration of a contaminated soil in Europe was based on a few critical levels defined in Annex 1st of Directive 86/278/EEC (CEC, 1986), and establishes limit values of concentration of metals in soils agricultural fertilized with sludge..$^{20}$ This directive was implemented as national laws in, with levels below those used in some countries (Netherlands, Denmark, Sweden). In Spain, Royal Decree 9/2005 of 14 January $^{21}$ considers the GF, which it calls "generic reference level" (GRL), as the basic parameter for evaluation by the Autonomous communities of soil contamination by certain substances. EU identifies five categories of potentially polluting activities of heavy metals: ${ }^{22,23}$

i. Industry: accidents, spills, leaks or leaks, storage and disposal.

ii. Mining activities: a generally associated with storage and deposition of tailings, acid mine drainage and the use of certain chemical reagents risk.

iii. Waste processing activities: It is estimated that $57 \%$ of municipal waste generated in the EU in a landfill; $87 \%$ in the EEC. ${ }^{24}$

iv. Traffic through emission, oils and gasoline losses, abrasion of rubber tires, etc.

v. Other activities: construction products used on the floor (concrete, paints), inadequate agricultural practices (use of fertilizers and pesticides) private and commercial storage (tanks, gas), water treatment systems, etc.

In Figure 1 it is represented the main sources of soil contamination by heavy metals according to available data. This type of polluting activities provides to soils heavy metals, Until They reach levels That Exceed the Proposed limits, Causing Often toxic effects to organisms. It is estimated, for example, that the addition of metals such as $\mathrm{Cd}$, $\mathrm{Cr}, \mathrm{Cu}, \mathrm{Pb}, \mathrm{Hg}, \mathrm{Mo}, \mathrm{Zn}$ and metalloid as is derived from industrial activities is approximately 10 to 20 times greater than the amount provided by natural weathering of geological materials. ${ }^{25}$ Some authors, as Nriagu \& Pacyna, ${ }^{26}$ also point out that the toxicity of heavy metals that were emitted per years exceeds the organic and radioactive contamination, assuming toxicity as a measure of the amount of water needed to dilute the concentration of contaminants to safe levels.
Local pollution of heavy metals associated with localized discharges, as discharges from industries such as metal smelting, whose impact reaches several kilometers from the emission source; ${ }^{27-29}$ acid drainage and runoff generated by the oxidation of materials pyritic type, mine slag heaps, which can reach values of $\mathrm{pH}<3$ causing the dissolution of metals; $;^{30-32}$ a high production of ash derived from coal combustion, which mobilizes significantly metals such as $\mathrm{Cd}$, Mo, $\mathrm{Zn}$ and metalloids such as As and $\mathrm{Se} ;, 6,30$ or the existence of a large number of different waste dumps, especially older ones built without containment barriers and pose a potential danger to the pollution of the deeper layers of soil and groundwater. ${ }^{33,34}$

Diffuse pollution of heavy metals associated with processes that affect large areas of land, such as atmospheric deposition, certain farming practices and inadequate waste recycling and wastewater. Atmospheric deposition represents one of the largest sources of heavy metals into the soil (Figure 1), ${ }^{35-37}$ with the deposition of volatile metalloid (se, $\mathrm{Hg}$, $\mathrm{As}$ and $\mathrm{Sb}$ ) or dust and/or fly ash mainly enriched in $\mathrm{Pb}, \mathrm{Cd}, \mathrm{Zn}, \mathrm{Cu}, \mathrm{Ni}$ and $\mathrm{V}$ (and motor vehicle emissions). Meanwhile, some agricultural production systems Involving the direct Addition During long periods of time of heavy metals, it is Associated to different fertilizers that contains, mainly $\mathrm{Cd}$ by the use of phosphates (in Europe an average of $\left.138 \mathrm{mg} \mathrm{Cd} \mathrm{kg}^{-1}\right)^{38}$ and not by the use of calcium nitrate. ${ }^{39}$ Also the use of manure from animals Often Involves With water pollution nitrates, salts and metals (mainly $\mathrm{Cu}$ and $\mathrm{Zn}$ ), ${ }^{10,40-42}$ or the addition of antibiotics and rich pesticides $\mathrm{Zn}$ salts, arsenates $\mathrm{Cu}$ and $\mathrm{Pb}$ and various organ metallic compounds ${ }^{43-46}$ or sewage sludge with varying concentrations of heavy metals. ${ }^{10,47,48}$

\section{Soil pollution in the European Union (EU)}

Following the publication of the "Thematic Strategy on Soil Protection" by the European Commission (CEC, 2002), various European countries are being forced to make an inventory of contaminated areas of its territory, which is currently available for more information on the magnitude of the existing problem. Table 2 indicates the estimated latest number of spaces (potentially) contaminated by country carried out in relation to the area of "artificial surfaces" (occupied by "urban factories" land, "industrial units, commercial and transport" and "mines, landfills and construction sites") obtained from the European database" Corine". ${ }^{49}$ Based on 
Corine 2000 and for Sweden in the most recent data land use Eurostat (Statistical Office of the European Communities)

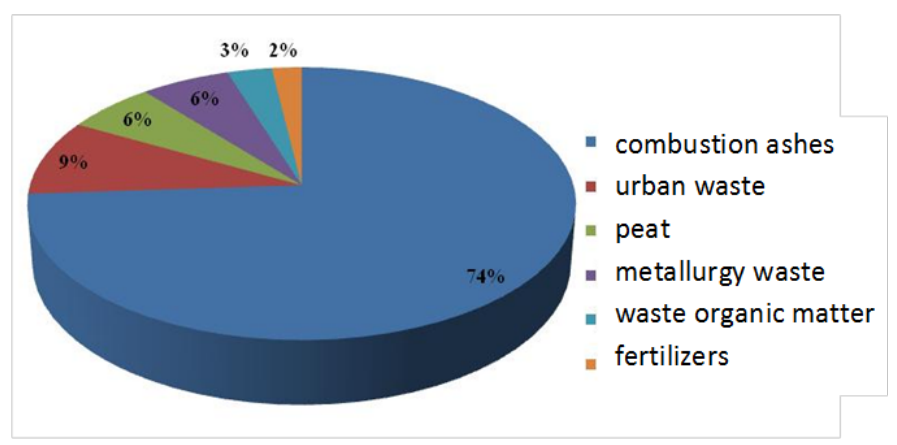

Figure I Main sources of origin of heavy metals in soils. ${ }^{36}$

The number of potentially contaminated sites extrapolated in the
EU25 is among 3'600,000 3'250,000/1000 $\mathrm{km}^{-2}$. The actual number of contaminated sites (where there is a risk to human health or the environment) was estimated at between 450,000 and $630,000 / 1000 \mathrm{~km}$ ${ }^{2}$. The amplitude of the estimated ranges is due to the difference in quality and degree of progress in inventories and heterogeneity of criteria that contaminated soils are defined, acceptable risks are quantified and instruments and characterization methodologies are adopted in different countries. As a final figure, we often speak of an estimate of about 3.5 million potentially contaminated sites in Europe, of which 0.5 million has been found that are actually contaminated and need to be restored. ${ }^{49}$

\section{Soil contamination in Asia and the Pacific}

Among the land degradation processes that are of particular concern in Asia and the Pacific include erosion, compaction, acidification, declining organic matter in soils, weed invasion, depletion of soil fertility and biological degradation.

Table 2 Extrapolation of the number of spaces (potentially) contaminated in the EU25, based on the area of "artificial surfaces" and using the estimated I4 countries $^{49}$

\begin{tabular}{|c|c|c|c|}
\hline & $\begin{array}{l}\text { Artificial surfaces I } \\
\left(1000 \mathrm{~km}^{2}\right)\end{array}$ & $\begin{array}{l}\text { Estimated number of } \\
\text { potentially contaminated spaces } \\
\left(\mathrm{N}^{\circ} / 1000 \mathrm{~km}^{2} \mathrm{~S} . \mathrm{A} .\right)\end{array}$ & $\begin{array}{l}\text { Estimated number of } \\
\text { contaminated sites } \\
\left(\mathrm{N}^{\circ} / 1000 \mathrm{~km}^{2} \text { S.A. }\right)\end{array}$ \\
\hline Austria & 1.5 & 20,000 & 1,667 \\
\hline $\begin{array}{l}\text { Belgium - } \\
\text { Flanders }\end{array}$ & 3 (est) & 25,000 & 3,667 \\
\hline Czech Republic & 4.2 & 1,185 & 119 \\
\hline Denmark & 2.4 & 12,500 & \\
\hline Finland & 2.4 & 8,333 & 2,708 \\
\hline France & 20 & 45,000 & \\
\hline Ireland & 0.7 & 3,286 & 2,686 \\
\hline Hungary & 5.1 & 5,882 & 588 \\
\hline Italy & 12 & 8,333 & \\
\hline Lithuania & 2 & 7,500 & \\
\hline Slovenia & 0.5 & 5,384 & \\
\hline Spain & 6.7 & 3,946 & \\
\hline Sweden & 5.2 & 10,865 & 2,211 \\
\hline Holland & 3.3 & $|8|,|8|$ & $|8| 8 \mid$, \\
\hline Total & $\begin{array}{l}\text { Total artificial surfaces } \\
14 \text { countries: } 69 \\
8 \text { countries: } 20\end{array}$ & $\begin{array}{l}\text { Total number of spaces for the I4 EU } \\
\text { countries dela } \\
\text { I' } 180,000 \\
\text { Weighted average for the } 14 \text { countries } \\
27,400 \text { spaces } / 1000 \mathrm{~km}^{2} \text { S.A.) }\end{array}$ & $\begin{array}{l}\text { Total number of spaces for the } 8 \mathrm{EU} \\
\text { countries dela } \\
95000 \\
\text { Weighted average for the } 8 \\
\text { countries } \\
3,800 \text { spaces } / / 1000 \mathrm{~km}^{2} \text { S.A.) }\end{array}$ \\
\hline $\begin{array}{l}\text { Extrapolated to } \\
\text { the total EU } 25\end{array}$ & $\begin{array}{l}\text { Total artificial surfaces } \\
\text { EU25 }\left(1000 \mathrm{~km}^{2}\right) \mid 19.3\end{array}$ & $\begin{array}{l}\text { Total number of potentially } \\
\text { contaminated sites for EU25 } 3 \text { '250,000 }\end{array}$ & $\begin{array}{l}\text { Total number contaminated spaces } \\
\text { for EU } 25450000\end{array}$ \\
\hline
\end{tabular}

The Global Assessment of Soil Degradation (GLASOD, according to its acronym in English) estimated that about 13 percent ( 850 million hectares) of land in Asia and the Pacific is degraded. ${ }^{50}$ Although most of the land is in Asia, there are 104 million degraded hectares in the Pacific subregion where the dismantling large-scale forest land has caused a decline in the structure and soil fertility and where invasive species are the cover predominant vegetation on many islands.

Chemical soil degradation is mainly attributed to agricultural mismanagement. In parts of northern India and Bangladesh, soils have been acidified and saline, also losing nutrients, while a significant 
proportion of land in Cambodia, Malaysia, Thailand and Viet Nam has been degraded because of the acid sulphate. ${ }^{50}$ It is common for there deficient nutrient balances in soils (between phosphorus, nitrogen and potassium) of Australia, Bangladesh, Nepal, Pakistan and Sri Lanka. Saline soils cover 60 million hectares of farmland in the region, and Australia in particular is facing severe land salinity problems. ${ }^{51}$ Excessive extraction of groundwater and surface water and the rise of the water table caused by faulty irrigation systems have increased the occurrence of surface water and soil salinity. ${ }^{42}$

Serious soil contamination problems are characteristic of the northern parts of the region, and parts of Australia and New Zealand. Among the contaminants include cadmium (contained in fertilizer), hexavalent chromium, lead, arsenic, trichlorethylene, tetrachlorethylene and dioxin concentrates. The health issues arising from chronic poisoning from agricultural land were common in the early seventies in the Pacific Northwest and Northeast Asia. ${ }^{52}$ The main contaminants from the soil in the region are now the chemical and electroplating industries in Japan and the Republic of Korea but heavy metals are also present in agricultural land (as a result of fertilizer application), and near mines and refineries (due to chemical spills). Soil contamination caused by lead and arsenic is prevalent throughout South and Southeast Asia. Irrigation with untreated effluent has also caused contamination and soil acidification in many areas; in Mongolia, for example, waste disposal and wastewater discharges are the main causes of soil contamination..$^{53}$

Action has been taken to address soil contamination, such as the Law on the prevention of pollution of soils and agricultural lands of Japan, in addition to restricting polluting activities, it has promoted recovery projects. In 1999, projects had been undertaken recovery for 79 percent of the total area of contaminated land (7,145 hectares). ${ }^{52}$ In the Republic of Korea, the Ministry of Environment established a network of pollution monitoring soil in 1996 to prevent contamination of adjacent mines soil, refineries, military bases, and storage facilities for oil and waste landfills. ${ }^{54}$ Australia has a nationally consistent approach to the assessment of site contamination through a national environmental protection measure (NEPM, according to its acronym in English) for the assessment of site contamination..$^{55}$

Many of the failures of physical reactions to the problems of land degradation originated from the competing influences of fiscal programs and business incentives. The practice of undercutting the price of resources and the granting of subsidies for agricultural inputs such as fertilizers have played important to continue exerting pressure on land papers. Insecure land tenure is a great conducive regulatory failure to land degradation, although in many cases even ownership is not enough to ensure sustainable use of land because population pressures have led to fragmentation and overexploitation of large estates. Political opponents of economic and environmental issues also influences land use practices in New Zealand. Government subsidies in the decades of the seventies and eighties transformed, as a result, large areas of forests and forest areas in pastures and crops, dramatically increasing the risk of erosion in these areas. However, since those subsidies were eliminated in the early eighties, has allowed vast areas of marginal pasture on steep land and regenerate in natural forest understory, reducing the risk of erosion..$^{56}$ Of the 1,977 million hectares of dry lands in Asia, more than half are affected by desertification. ${ }^{57}$ The worst affected area is Central Asia (more than 60 percent are affected by desertification), followed by South Asia (over 50 percent) and Northeast Asia (about 30 percent). In Figure 2 illustrates a map that shows this information.

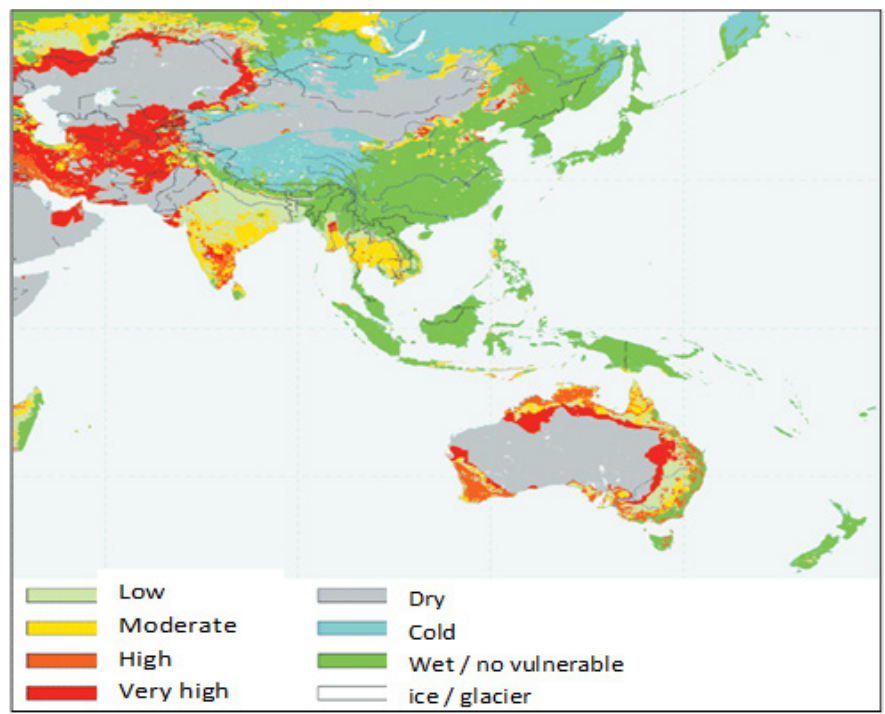

Figure 2 Vulnerability and desertification in Asia and Pacific

Activities to combat desertification include watershed management, soil conservation and water, dune fixation, reforestation programs, reclamation of waterlogged and saline lands, forest and rangeland management, and recovery soil fertility. In India, among the programs started from the early nineties, there may be mentioned Afforestation Program, the Program drought-prone areas (1994-1995), the Development Program on deserts, national Project watershed development for dry areas (1990-1991), the Indira Gandhi Nahar project (encouraging local community participation) and the environmental action Programme 1993. ${ }^{58}$

\section{Soil contamination on the African continent}

Africa is one of the least developed continent and suffers various environmental problems among the most serious is the contamination by chemicals. The most important economic activities on this continent is agriculture, extraction of mineral resources and metals but the way they are done you are highly polluting and harmful are. Each year 500,000 workers die in Africa by chemical pollution from pesticides and other chemicals such as cyanide, DDT, banned in many other countries, etc. that are used to develop these industries. But also they pollute towns and entire population's kilometers from where farms are already covering pollution to air, soil, surface water and groundwater, flora and fauna. Another problem is that entering this continent toxic waste from outside, but they are not given proper treatment only accumulate becoming potential risk of environmental pollution.

In African transnational corporations have a double standard, since there using the dirtiest methods and processes because they are cheaper but know they are highly damaging and harmful to the health of people and the environment. While in the countries of origin or subsidiaries in developed countries carry out its as clean and sustainable activities possible. They take advantage of that in these countries are desperate for investment of foreign capital and have a strong and effective environmental legislation to prevent companies from contaminated and if they do pay and should compensate the losers and restore environmental damage. The African continent has much of its population in extreme poverty and if we add the consequences on the health of thousands of people causing enterprises, the social 
situation is even worse. Corporate social responsibility should be required in all countries, most in places where social reality is very hard.

\section{Soil contamination in Mexico}

As a result of several centuries of mining in Mexico and later, due to basic industry, petrochemical and oil refining chemical, there are very large amounts, but very difficult to quantify hazardous waste. In addition to this, the intense activity of other industries, along with accidents during storage, transport or transfer of substances (leaks, spills, fires) and illegal and uncontrolled waste disposal, contribute greatly to soil contamination. ${ }^{59}$ The number of contaminated sites, even the most conservative estimates, amounts to several thousand places whose potential risk is unknown. According to data published by the INEGI, ${ }^{60}$ the surface of soil degraded by pollution causes in 1999 (as reported) it was $25.967 \mathrm{~km}^{2}{ }^{61}$

In all events that are involved substances that involve some risk to the environment or the population and could cause pollution to soil or water bodies are known as environmental emergencies. According to statistics from the Federal Attorney for Environmental Protection (PROFEPA), they are presented each year in Mexico an average of 550 environmental emergencies associated with hazardous materials and wastes. Within the hazardous ingredients most commonly involved in environmental emergencies, are the petroleum and petroleum products (gasoline, fuel oil, diesel), agrochemicals, LP and natural gas, among others (Figure 3).

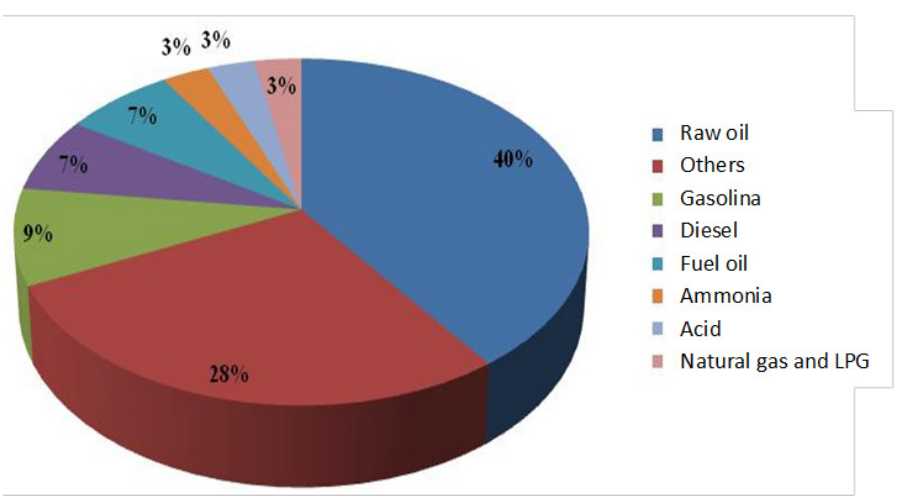

Figure 3 Main substances involved in environmental emergencies reported to Profepa between 1997 and $1999 .{ }^{62}$

Among the pollutants that are considered priority in Mexico because of its high toxicity and its persistence in the environment, they are the following: dioxins, furans, hexachlorobenzene, polychlorinated biphenyls (PCBs), organ chlorine pesticides, mercury, lead, chromium, cadmium, air toxics compounds and poly aromatic hydrocarbons (PAHs). Compounds such as PCBs have been stored in drums on many occasions, have been arranged clandestinely. Meanwhile, PAHs are found as components of total petroleum hydrocarbons (HTP). As mentioned, there are nationwide pollution problems still not precisely quantified. However, there may be mentioned qualitatively pollution problems generated by the use of agrochemicals, both fertilizers (especially nitrogen) and pesticides (fungicides, herbicides and insecticides); which they are a result of the spill and leak fuel (oil and derivatives), as well as those related to mining activities in their stages of extraction and the processing of the materials obtained ${ }^{63}$ Due to the increasing volume of hazardous waste generated in our country and existing capacities for management often clandestine disposal of these it comes in various places (municipal dumps, vacant lots, yards of enterprises, drains), thereby causing an increase in sites contaminated with dangerous substances of organic and inorganic nature. In Table 3 it shows that in period from 1995 to 1998, cases of illegal sites or abandoned, Which Were detected by PROFEPA, where waste is dumped hazardous waste from various industries.

Table 3 Types of Hazardous Waste Found as Major pollutants in this abandoned sites and/or Illegal Several States of Mexico

\begin{tabular}{|c|c|c|}
\hline State & $\begin{array}{l}\text { Number } \\
\text { of sites }\end{array}$ & Major waste* \\
\hline $\begin{array}{l}\text { Baja California } \\
\text { Norte }\end{array}$ & 8 & Oils, mineral, casting powders, solvents \\
\hline $\begin{array}{l}\text { Baja California } \\
\text { Sur }\end{array}$ & 2 & Smelting slag, tailings \\
\hline Campeche & 4 & Oil, drilling mud \\
\hline Chiapas & 17 & Hydrocarbons, pesticides, solvents \\
\hline Chihuahua & 13 & Oils, hydrocarbons, chemicals \\
\hline Coahuila & 15 & $\begin{array}{l}\text { Oils, hydrocarbons, mining tailings, } \\
\text { chemicals }\end{array}$ \\
\hline Durango & 3 & Hydrocarbons, insecticides \\
\hline $\begin{array}{l}\text { Estado de } \\
\text { México }\end{array}$ & 10 & Oils, smelting slag, chemical \\
\hline Guanajuato & 10 & $\begin{array}{l}\text { Oils, smelting slag, sludge, metals, organ } \\
\text { chlorines }\end{array}$ \\
\hline Hidalgo & 6 & Tailings, slag casting, painting \\
\hline Jalisco & 7 & $\begin{array}{l}\text { Diesel and fuel, batteries, sludge, } \\
\text { chemical }\end{array}$ \\
\hline Nayarit & 5 & Hydrocarbons, tailing \\
\hline Nuevo León & 22 & $\begin{array}{l}\text { Oils, cyanides, foundry slag, } \\
\text { hydrocarbons, metals }\end{array}$ \\
\hline San Luis Potosí & 10 & $\begin{array}{l}\text { Asbestos, smelting slag, sludge, metals, } \\
\text { paints }\end{array}$ \\
\hline Sinaloa & 4 & agrochemicals \\
\hline Tamaulipas & 8 & Oils, smelting slag, chemical \\
\hline Veracruz & 8 & Sulfur, hydrocarbons \\
\hline Zacatecas & 9 & Jales, metals, chemicals \\
\hline Total & 161 & \\
\hline
\end{tabular}

In the period 1995-1998, 161 abandoned sites contaminated with hazardous waste in 18 of the 32 states of the Republic were detected. However, it is estimated that the number of such sites containing hazardous waste is much higher and it is unknown. Since 1988, more than 27 thousand companies have complied with the obligation to report the generation of hazardous waste. However, the universe of generating companies that do not report and dispose of their waste illegally is unknown, and it is estimated that the potential universe is greater than $100,000 / 1000 \mathrm{~km}^{-2}{ }^{2}{ }^{61}$ According to this information within hazardous waste found most often in clandestine dumps waste from the mining industry (tailings, metals and foundry slag) and petrochemical (oil and chemical) are also spent oils from mechanical workshop. 
In the period 1995-1998, 161 abandoned sites contaminated with hazardous waste in 18 of the 32 states of the Republic were detected. However, it is estimated that the number of such sites containing hazardous waste is much higher and it is unknown. Since 1988, more than 27 thousand companies have complied with the obligation to report the generation of hazardous waste. However, the universe of generating companies that do not report and dispose of their waste illegally is unknown, and it is estimated that the potential universe is greater than $100,000 / 1000 \mathrm{~km}^{-2}{ }^{61}$ According to this information within hazardous waste found most often in clandestine dumps waste from the mining industry (tailings, metals and foundry slag) and petrochemical (oil and chemical) are also spent oils from mechanical workshop.

\section{Environmental risk - mobility and bioavailability of metals}

The chemical forms in which the metals are found in soil and greatly mobility and bioavailability between them is determined by the set of the different components of soil and chemical, physical and biological factors affecting the reactivity of such components. ${ }^{64-66}$ Trace elements of a soil is divided between a water-soluble fraction, in interchangeable positions of clay and organic matter, together with oxides, carbonates, sulfates and phosphates, complexed organic matter and within the crystal lattices of the residual fraction (Figure 4). ${ }^{67,68}$ The balance of the metals between different soil components is regulated by a number of biotic and abiotic processes that govern their behavior and determine their stay in one compartment or the other, that is, its biogeochemical speciation. This results in a dynamic and exchange of items between the different phases that maintains a system of quasi-equilibrium under field conditions. ${ }^{64}$

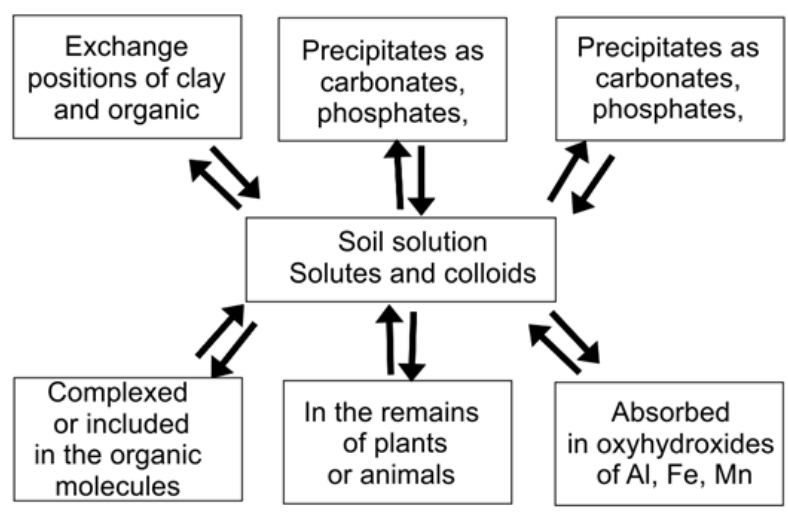

Figure 4 Compartmentalization of heavy metals in the soil. ${ }^{69}$

The Processes governing the biogeochemical speciation of metals in soils result in reactions of precipitation - dissolution and reactions adsorption-desorption, Which Directly Affect the distribution of metals Between solid and aqueous phase and complexation reactions and oxidation - reduction Affecting the reactivity of the metal itself (solubility and bioavailability). ${ }^{70}$ These reactions are controlled by environmental factors such as $\mathrm{pH}$, cation exchange capacity (CEC), the redox potential and the type itself and chemical speciation of the elements. ${ }^{16,71}$

The $\mathrm{pH}$ is considered the dominant factor in the behavior of metals, since it affects the surface charge of the clay, organic matter and oxides of $\mathrm{Fe}$ and $\mathrm{Al}$ and influences the complexation of metals with organic matter in the precipitation reactions, dissolution, redox reactions and colloid dispersion. $\mathrm{A} \mathrm{pH}$ increase causes an increase in the absorption and retention of cations with a maximum around neutrality. ${ }^{72}$ Exceptions with Mo, V, Cr (III) and metalloids such as and $\mathrm{Se}$, commonly less mobile under acidic conditions. ${ }^{10}$ In the case of $\mathrm{Cd}$, solubility increases with decreasing $\mathrm{pH}$ from a value $\mathrm{pH}$ 6.5. $\mathrm{Pb}$ and $\mathrm{Hg}$ begins from $\mathrm{pH} 4$, while other elements such as $\mathrm{As}, \mathrm{Cr}, \mathrm{Cu}$ and $\mathrm{Ni}$ begins to solubilize at $\mathrm{pH}$ values between these two extremes. ${ }^{71}$

The cation exchange capacity (CEC) of soils is largely dependent on the surfaces of adsorption determined by the amount and type of clay, organic matter $(\mathrm{OM})$ and oxides of $\mathrm{Fe}, \mathrm{Al}$ and $\mathrm{Mn} .{ }^{73}$ In general, the higher the clay content, the greater the CIC and therefore greater the amount of metal that can be held without potential danger, since the solubility and mobility of metals is limited. ${ }^{68}$ The 2:1 clays (montmorillonite and vermiculite) also have much higher CEC values than $1: 1$ (kaolinite). ${ }^{74}$ The adsorption capacity of the oxides of $\mathrm{Fe}, \mathrm{Al}$ and $\mathrm{Mn}$ can also play an important role in controlling and immobilizing metals in soils. ${ }^{43}$ Furthermore, some heavy metals such as $\mathrm{Co}, \mathrm{Cu}, \mathrm{Hg}, \mathrm{Y}, \mathrm{Pb}$ and $\mathrm{Zn}$ have high affinity to organic matter, forming soluble and insoluble complex. Organic matter has both the ability to complexation as cation exchange. ${ }^{48}$

Complexation processes occur as an exchange reaction with water molecules coordinated, which are exchanged for some ligands, which can be described by the principle of strong and weak acids and Lewis bases. Protons and all metal cations of interest in the soil solution are Lewis acids, while Lewis bases include $\mathrm{H}_{2} \mathrm{O}$, oxyanions $\mathrm{OH}^{-}, \mathrm{SO}_{4}^{-}$ ${ }^{2}, \mathrm{PO}^{-3}, \mathrm{COO}^{-}, \mathrm{CO}_{3}^{-2}, \mathrm{~F}^{-}, \mathrm{NO}_{3}^{-}$and organic compounds as $\mathrm{N}, \mathrm{S}$ and $\mathrm{P}$ electron donors. According to the principle of Lewis, bases strong are complexed more easily with strong acids and weak bases with weak acids, all under comparable conditions of acid-base strength. ${ }^{75}$ These bonds are much stronger, this because the ions penetrate the crystal structure, and are linked by covalent bonds via oxygen atoms or hydroxyl groups.

The moisture content of the soil is another important factor governing metal speciation and mobility through oxidation-reduction reactions. Under reducing conditions can form metal sulphides, which are quite insoluble, so that mobility and bioavailability are considerably lower than those expected under oxidizing conditions. Analyzing an extracted solution of a floor, which is treated with iodine, indicates for example, decreased solubility of $\mathrm{Cd}, \mathrm{Cu}$ and $\mathrm{Zn}$ and increasing the solubility of $\mathrm{Mn}$ and $\mathrm{Fe}$ under reducing conditions. ${ }^{76}$ Furthermore, it is known that the chemical nature of the mineral surfaces is the most significant factor contributing to the retention / mobility of contaminants, and these properties are generally considered invariable during the exposure time and reaction of the pollutant. Studies show, however, that the mineral surface chemistry is extensively modified by changes in the oxidation state of the $\mathrm{Fe}$ in the crystalline mineral structure, assuming a great impact on the chemical environment. The redox activity of the mineral surface affects the oxidation state, and consequently speciation and chemical behavior of ionic metals sensitive to redox reactions aqueous phase (such as $\mathrm{Cr}$, which can go from $\mathrm{Cr}^{6+}$ to $\mathrm{Cr}^{3+}$, less mobile and dangerous).

Finally, some of the physicochemical properties of the elements, as electro negativity, ionic strength and the diameter of the hydrated ion in aqueous solution, have influence on the behavior of metals biogeochemical. Electro negativity influences the order in which the heavy metals are absorbed by soil constituents, the more 
electronegative metals tend to form strong covalent bonds with oxygen atoms on the surface. For some divalent metals, binding preferences could be: $\mathrm{Cu}>\mathrm{Ni}>\mathrm{Co}>\mathrm{Pb}>\mathrm{Cd}>\mathrm{Zn}>\mathrm{Mg}>\mathrm{Sr} .{ }^{10}$ However, it also influences the binding forces, ionic potential, and preferences can be: $\mathrm{Ni}>\mathrm{Mg}>\mathrm{Cu}>\mathrm{Co}>\mathrm{Zn}>\mathrm{Cd}>\mathrm{Sr}>\mathrm{Pb} .{ }^{10}$ Trivalent trace metals as $\mathrm{Fe}^{+3}$ and $\mathrm{Cr}^{+3}$ may be preferentially adsorbed this in presence of divalent metals listed above. Similarly, it should be mentioned that Mn oxides show a particularly strong preference for the adsorption of $\mathrm{Cu}, \mathrm{Ni}, \mathrm{Co}$ and $\mathrm{Pb}$, while oxides of $\mathrm{Fe}$ and $\mathrm{Al}$ preferentially adsorb $\mathrm{Pb}$ and $\mathrm{Cu} .{ }^{77}$

Because of this variety of factors, mobility and risk of toxicity to different organisms and human health due to the presence of metals, it cannot be solely based on the total concentration of the element in question, but rather in their physical chemical state. ${ }^{78-80}$ The bioavailability of the elements refers to biologically available forms that can become absorbed by the organisms and integrated into your metabolism, ${ }^{81}$ this will depend mainly on the species in which the metals are in the soil and the absorptive capacity of the organism self. In fact, absorption and toxicity of many metals, depend on the chemical species in which the metal is located, and are often correlated with the activity of free metal ion..$^{38,92}$

The process of sequential extraction it is a frequently used tool for the fractionation of metals in soil, ${ }^{83,84}$ and it allows us to identify the main points of union and associations of trace elements in different soil constituents. This allows evaluating the potential remobilization of metals and the risk of release towards the dissolution of soil. ${ }^{85}$ Likewise, there are and have been used some simple extraction methods to study the ecotoxicity and mobility of metals in soils, to determine the fraction of bioavailable metal. They have been used a variety of extractants, such as strong acids, or solutions of neutral salts, may be buffered or unbuffered, and metal complex agents. ${ }^{83,86}$ Some of them are widely used, such as EDTA, DTPA, or the mixture of ammonium/EDTA acetate, which often cause good correlations between the extracted metals and absorbed by plants.

\section{Recovery of contaminated soils}

In the "Thematic Strategy on Soil Protection" launched by the European Commission ${ }^{49}$ it provides that Member States of the EU must ensure that actions are taken to restore contaminated sites identified within their national territory. The restoration should consist of actions on the ground which can extract, control, contain or reduce pollutants in a given area, considering its current use and future use, also preventing any significant risk to human health and the environment. It is assumed that all contaminated areas identified must be restored in a time of 30-50 years, having to hold the state of those places where no owner or itself cannot bear the costs of restoration (Directive 2004/35/EC ${ }^{49}$ ).

Restoration objectives defined in "National Restoration Strategy" and were ordered the priority which must be recovered contaminated sites. In Spain, the National Plan of recovery of contaminated soil (NPRCS) raised among its objectives the recovery of 275 contaminated soil, giving priority to the 61 sites already identified as most at risk, representing the order of 38 million $\mathrm{m} 3$ of soil and more than 9 million $\mathrm{m}^{3}$ groundwater. The number of sites that finally managed to regain was $212,{ }^{87}$ which according to data collected in the NPRCS, more than $98 \%$ of potentially contaminated sites in Spain remain at waiting to be recovered. The waste law 98 (BOE No. 96, 1998) states that "the declaration of a soil as contaminated compelled to carry out the actions necessary to proceed with the cleanup and recovery, in the form and time in determining the respective. In addition to this, the Royal Decree 9/2005 of 14 January, ${ }^{21}$ Article 7 states that:

i. The scope and implementation of recovery actions will be such as to ensure that the remaining contamination, if any, will result in acceptable risk levels according to land use.

ii. The recovery of contaminated soil will be done using the best techniques available, depending on the characteristics of each case. Recovery actions must ensure that materialize permanent solutions, giving priority, as far as possible, in situ treatment techniques that avoid the generation, transfer and disposal.

iii. Whenever possible, the recovery will be oriented to eliminate sources of pollution and to reduce the concentration of contaminants in the soil. In the event that for reasons justified technical, economic or environmental nature that recovery is not possible, it may be assumed recovery solutions designed to reduce exposure, provided they include containment measures or containment of soils affected.

Nowadays, there are many contaminated soil recovery technologies with heavy metals; some are of common application and others still in the experimental stage. All are designed to isolate or remove pollutants altering its chemical structure by physicochemical thermal or biological processes (Table 4).

The European Commission refers to the principle of "Best Available Technology" (BAT), ${ }^{22}$ Assuming, that the choice of the technology to treat contaminated soil, always depend on the specific characteristics of the site to be decontaminated; the BAT principle includes a summary of the steps, key decisions and actions to be carried out to identify the most appropriate recovery technique for a given contaminated site (Table 5).

Other useful tools for choosing the most appropriate soil recovery technique have been given by the EPA (United States Environmental Protection Agency), who published the 4th edition of "Routes to technologies for investigation and decontamination of contaminated soils" $" 89$ in order to provide information and help identify and select innovative technologies for the characterization and remediation of soil. Another source of information of interest is "Technology Tree", 90 which has an extensive glossary of terms and information about technology facilitates recovery and, also, access to databases and other sources with additional information.

\section{Phytoremediation of contaminated soils}

The final choice of restoration technique, in any case, largely depends on the soil characteristics and the nature and degree of contamination, the innovative availability and cost of the technique, the estimated development time and finally the function or use you want to give the area restored. ${ }^{91}$ The preference of the use of "in situ" treatment is generally derived from involving lower costs, less destruction and enviromental alteration, although usually is more slower and more difficult to implement, given the difficulty of putting in direct contact decontaminating agents with the entire surface of the contaminated soil. Considering the destructive effects of soil and/or the high costs of physico-chemical and thermal treatments; biological treatments employing microorganisms and plants, are a set of promising techniques for the recovery of contaminated soils. In Tables 6 and Table 7 are shown a comparative of the most used techniques for bioremediation, techniques "in situ" (Table 6), "ex situ" Table 7 and Table 8 shows the advantages and Disadvantages of bioremediation. 
Table 4 Main treatment of soil contaminated with heavy metals

\begin{tabular}{|c|c|c|c|}
\hline Type of treatment & & Treatment & Aplication \\
\hline & & Physico-chemical stabilization & Ex situ \\
\hline \multirow[t]{4}{*}{ Confinement } & & Solidifying injection & In situ \\
\hline & & Vitrification & Ex situ-In situ \\
\hline & & Vertical barriers & In situ \\
\hline & & Horizontal barriers & In situ \\
\hline \multirow[t]{9}{*}{ Containment } & & Barriers dry soil & In situ \\
\hline & & Sealed deep & In situ \\
\hline & & Hydraulic barriers & In situ \\
\hline & & Extraction & In situ \\
\hline & & Washing & Ex situ \\
\hline & & Flushing & In situ \\
\hline & Physical chemistry & Electro kinetic & In situ \\
\hline & & Adding amendments & In situ \\
\hline & & Active permeable barriers & In situ \\
\hline \multirow{8}{*}{ Decontamination } & & Incineration & Ex situ \\
\hline & Thermal & Thermal desorption & Ex situ \\
\hline & & Biotransformation metal & In situ \\
\hline & & Landfarming & Ex situ \\
\hline & & Biocells & Ex situ \\
\hline & Biological & Composting & Ex situ \\
\hline & & Phytoremediation: & \\
\hline & & $\begin{array}{l}\text { i. Phytoextraction } \\
\text { ii. Phytostabilization }\end{array}$ & In situ \\
\hline
\end{tabular}

Table 5 Concepts to consider for choosing the best recovery technology available in each case (principle BAT). ${ }^{22}$

Main stages of Key decisions of each stage
evaluation of
options

options

I. Set restoration objectives to be achieved

a. What specific techniques restoration of the position and what goals should be

Identification of considered when selecting technique?

Dining options

Is there enough data?

(Stage I)

c. What restoration options

II. Review existing data to decide if there is enough information available to produce a list of potential decontamination techniques.

III. Produce a short list of potential decontamination techniques using the following factors:

a. It is effective in relation to the substance and its properties?

b. It is effective in relation to pollution for the type of location / environment?

c. it is effective and durable pollution related to the use of a specific preferred strategy (that is, trying the source, breaking transport routes and/or controlling elreceptor)? 
Table 6 Comparative table of in situ bioremediation techniques

\begin{tabular}{|c|c|}
\hline Technique & Characteristics \\
\hline Bioaccumulation & $\begin{array}{l}\text { It is addition of nutrients to the microorganisms, being used for a contaminant degradation with controlling } \\
\text { temperature, humidity, } \mathrm{pH} \text { and the electron acceptors; Some of the Most Important nutrients are, nitrogen, } \\
\text { phosphorus and carbon, all these are necessary for metabolism and growth rate of biodegradable organisms, and } \\
\text { it accelerates biodegradation rates when environmental conditions are favorable: }{ }^{92-94} \text { In most of these studies was } \\
\text { able to increase the biodegradation activity, only with the addition of nutrients in the form of inorganic fertilizers } \\
\text { compounds. }{ }^{95-98}\end{array}$ \\
\hline Phytoremediation & $\begin{array}{l}\text { In addition to microorganisms, plants also play a major role in cleaning up the environment. Phytoremediation is a } \\
\text { process by which plants are used for cleaning contamination by heavy metals in soil and water }{ }^{99}\end{array}$ \\
\hline Phytoextraction & $\begin{array}{l}\text { It is use of plants that can carry and concentrate metals from the soil on the roots. The roots of sunflowers have } \\
\text { been used to treat water containing } \mathrm{Pb}, \mathrm{U}, \mathrm{Sr}, \mathrm{Cs}, \mathrm{Co} \text { and } \mathrm{Zn} \text {; other plants with this potential are poplar and water } \\
\text { hyacinth. } 99\end{array}$ \\
\hline Rizodegradation & $\begin{array}{l}\text { It is the biodegradation of organic pollutants through the microbial biodegradation by plants, this degradation is } \\
\text { carried out in the rhizosphere, the land area around the roots of plants containing more microbial populations and } \\
\text { activity; the roots of plants exuding organic acids, phenolic compounds, enzymes and proteins that affect systems } \\
\text { of bacteria living in the soil. The metabolisms of rizodegradation are the same as the microbial degradation, with } \\
\text { the difference that in the rizodegradation, they have been improved microbial processes of plants and their root } \\
\text { systems. }{ }^{99} \text { They are used for this process, bacteria of the genus Rhizobium, these help the roots move towards the } \\
\text { depths of the soil and to reach the contaminants and they are adsorbed. }\end{array}$ \\
\hline Phytostabilization & $\begin{array}{l}\text { Process in which the plants are used for immobilizing metals in the soil, minimizing their mobility in the liquid } \\
\text { phase. Plants are able to immobilize soil contaminants by adsorption, accumulation in roots or precipitation in } \\
\text { the area of the roots; and thereby preventing migration of the contaminants, minimizing erosion, leaching and } \\
\text { dispersion in the soil.9 }\end{array}$ \\
\hline Phytovolatilisation & $\begin{array}{l}\text { This process involves the uptake and transpiration of contaminants by plants. It applies primarily to groundwater, } \\
\text { but can be applied to sludges, sediments and soils. It is used to remove chlorinated solvents eg, selenium, mercury } \\
\text { and arsenic. When pollutants are adsorbed and captured the metabolic processes of the plant they begin their } \\
\text { functions and begin to convert into other compounds or volatilize into the atmosphere. }{ }^{99}\end{array}$ \\
\hline Phytodegradation & $\begin{array}{l}\text { This process is based on the break and adsorption of organic pollutants, through the metabolism of plants. This } \\
\text { phytoremediation process is not applicable to inorganic contaminants such as metals, and that they are not } \\
\text { biodegradable. }{ }^{99}\end{array}$ \\
\hline Bioventilación & $\begin{array}{l}\text { It is a relatively new technology that stimulates the natural degradation of any compound biodegradable } \\
\text { under aerobic conditions. Air is supplied to the contaminated site through extraction wells forced movement } \\
\text { (extraction or injection) with low flow rates to provide the oxygen needed to sustain the activity of the degrading } \\
\text { microorganisms. }{ }^{100} \text { It is used to treat biodegradable volatile organic compounds (VOCs); or nonvolatile. Promotes } \\
\text { the degradation of contaminants adsorbed can reach degrade volatile organic compounds (VOCs). }{ }^{101} \text { It has been } \\
\text { used to decontaminate soils with non-chlorinated solvents, pesticides and some wood preservatives and other } \\
\text { chemicals. }{ }^{100}\end{array}$ \\
\hline $\begin{array}{l}\text { Bio-injection (Air } \\
\text { sparging) }\end{array}$ & $\begin{array}{l}\text { It is a method used for the removal of VOCs, both the solid phase and the liquid phase. The characteristics } \\
\text { of the contaminant to use this method must be high volatility, low solubility and low adsorption coefficient. } \\
\text { Thus the contaminant will tend to move to the gas phase of the soil during the application of the method. The } \\
\text { physiochemical mechanisms is a contaminant desorption process achieved by forced air circulation within the soil } \\
\text { matrix. Air is pressed into the ground through a well practiced to a point below the contaminated zone, volatile } \\
\text { pollutants are carried by the injected air and collected by extracting vapors. }{ }^{102}\end{array}$ \\
\hline
\end{tabular}

\section{Phytoremediation process optimization research routes}

Over the past decade, there have been scientific papers studying the evolution and process optimization of phytoremediation of heavy metal contaminated soils, ${ }^{106-109}$ mainly focusing on the following aspects: ${ }^{110-112}$

I. Identify, select and optimize candidate plants for genetic selection and other performances.

II. Optimize agronomic and silvicultural use of fertilizers, irrigation, pest control and other practices Hyperaccumulator plants.

III. Rhizosphere manipulation by selecting roots, treatment with amendments, and inoculation with bacteria and fungi selected.

IV. Expand knowledge of the metabolic and genetic engineering used to create transgenic plants economically viable.

Phytoremediation encompasses a group of emerging techniques based on the use of plants and its partners to extract, accumulate, immobilize or transform contaminants from soil microorganisms (Figure 5). ${ }^{113-116}$ 
Table 7 Comparative table of ex situ bioremediation techniques

\begin{tabular}{|c|c|}
\hline Technique & Characteristics \\
\hline Biopiles & $\begin{array}{l}\text { It is defined as a controlled biological process where organic contaminants are biodegraded and mineralize. Biopiles } \\
\text { are a bioremediation technology in which soil contaminated with hydrocarbons, for example, is extracted and arranged } \\
\text { in an area of excabada treatment for decontamination with microorganisms. They are used when the pollutant is } \\
\text { too volatile to be treated with the Land farming, or when the gaseous emissions may be too high, or when required } \\
\text { to accelerate the process of bioremediation. Soil treatment with biopiles applies primarily to the removal of VOCs } \\
\text { unhalogenated, semivolatile pesticides; although the process efficiency may decrease and only be applicable to some } \\
\text { compounds. }{ }^{103,104} \text { Costos: } 125-165 € / \mathrm{m}^{3} \text { de suelo. }\end{array}$ \\
\hline Bioreactors & $\begin{array}{l}\text { It is a technique that uses a mixture of contaminated soil, sludge, water and additives to promote biodegradation } \\
\text { increasing contact between microorganisms and pollutants within a reactor (bioreactor). It applies to explosives, } \\
\text { plaguicide,VOC solvents. The bioreactors can be sequential aerobic and anaerobic. }\end{array}$ \\
\hline Composting & $\begin{array}{l}\text { Mixture of soils contaminated with organic amendments and porous materials as sawdust, straw, manure, plant debris; } \\
\text { to promote biodegradation and increased temperature. They apply to explosives, trying to maintain oxidizing conditions } \\
\text { (aeration) moisture (irrigation) and temperature }\left(54-65^{\circ} \mathrm{C}\right) \text {. Uses methods of aeration, mechanical mixing (the most } \\
\text { used), static (or injection pump) and mechanical agitation in containers. }\end{array}$ \\
\hline Landfarming & $\begin{array}{l}\text { In this method must be distributed the contaminated soil in linear layers, It should flip periodically to promote aeration; } \\
\text { this also improves the conditions to stimulate biodegradation (moisture, nutrients, etc.). It applies to petroleum } \\
\text { hydrocarbons (noVOCs), fuels and some pesticides. Degrade, transform and immobilizes contaminants. }\end{array}$ \\
\hline
\end{tabular}

Table 8 Advantages and Disadvantages of bioremediation ${ }^{105}$

\begin{tabular}{|c|c|}
\hline Advantages & Disadvantages \\
\hline $\begin{array}{l}\text { Generally, minor physical changes originates on the } \\
\text { environment }\end{array}$ & For many types of discharges its effectiveness has not been determined \\
\hline $\begin{array}{l}\text { When it used correctly does not produce significant adverse } \\
\text { effects }\end{array}$ & It is very difficult to apply in the sea \\
\hline It may be useful to remove some of the oil toxic compounds & The time required for performance is very long \\
\hline $\begin{array}{l}\text { Offers a simple and complete solution that mechanical } \\
\text { technologies }\end{array}$ & Its implementation is specific to each site contaminated \\
\hline Less expensive than other technologies & $\begin{array}{l}\text { Optimization requires substantial information about the contaminated } \\
\text { site and the characteristics of the discharge }\end{array}$ \\
\hline $\begin{array}{l}\text { They usually have lower costs than incineration, used to } \\
\text { remove toxic substances from soil }{ }^{101}\end{array}$ & Difficulty in predicting the performance of this treatment ${ }^{101}$ \\
\hline
\end{tabular}

\section{Geobotánica search and biogeochemical prospecting} for new species

The identification of new plant species accumulating metals, ${ }^{111}$ increases the number of plants that can be used in phytoextraction, this fact potentiates the possibility of selecting new plants able to tolerate different metals and soil conditions $(\mathrm{pH}$, salinity, soil structure, water content, etc.), and having the physiological conditions to suit different areas and with different resistance to disease and insect attack. ${ }^{117}$ Hyperaccumulator plants that are known so far belong to specific plant communities adapted to environments with high levels of metals in the soil. ${ }^{118,119}$ Reeves \& Baker ${ }^{120}$ they indicate the existence of four main types of metalliferous soils that harbor hyperaccumulators; as serpentiníticos soils that are derived from ultramafic rocks rich in $\mathrm{Fe}$ and $\mathrm{Mg}$; seleníferos these soils derived from some types of rocks rich in $\mathrm{Se}$; calaminos soil enriched with $\mathrm{Zn}, \mathrm{Cd}$ and $\mathrm{Pb}$; and finally the soils rich in $\mathrm{Co}$ and $\mathrm{Cu}$ which are derived from shales and dolomites.
Considering the diversity of plants and their responses to different levels of metals, prospecting of biodiversity in these ecosystems could allow the identification of new wild plants that could be used in phytoremediation techniques. In this sense, serpentiníticos soils function as an important source of hyperaccumulator plants and spread throughout the world, occupying about $1 \%$ of the land surface. ${ }^{119,121}$ Serpentinicola plant communities present a large group of hyperaccumulators, and are therefore of particular interest to the search for new species adapted to high levels of metals in soil and with a great capacity for accumulation of metals in their tissues. In the Iberian Peninsula, for example, there are three serpentiníticas areas (in A Coruna, Tras-os-Montes and Malaga) characterized by having abnormally high contents of trace elements such as $\mathrm{Ni}, \mathrm{Cr}, \mathrm{Cu}$ and Co. ${ }^{122}$ This metal content in many cases exceed the values considered critical by the CEC (Commission of the European Communities) and produce phytotoxicity in "normal" plants not adapted to this type of environment. 


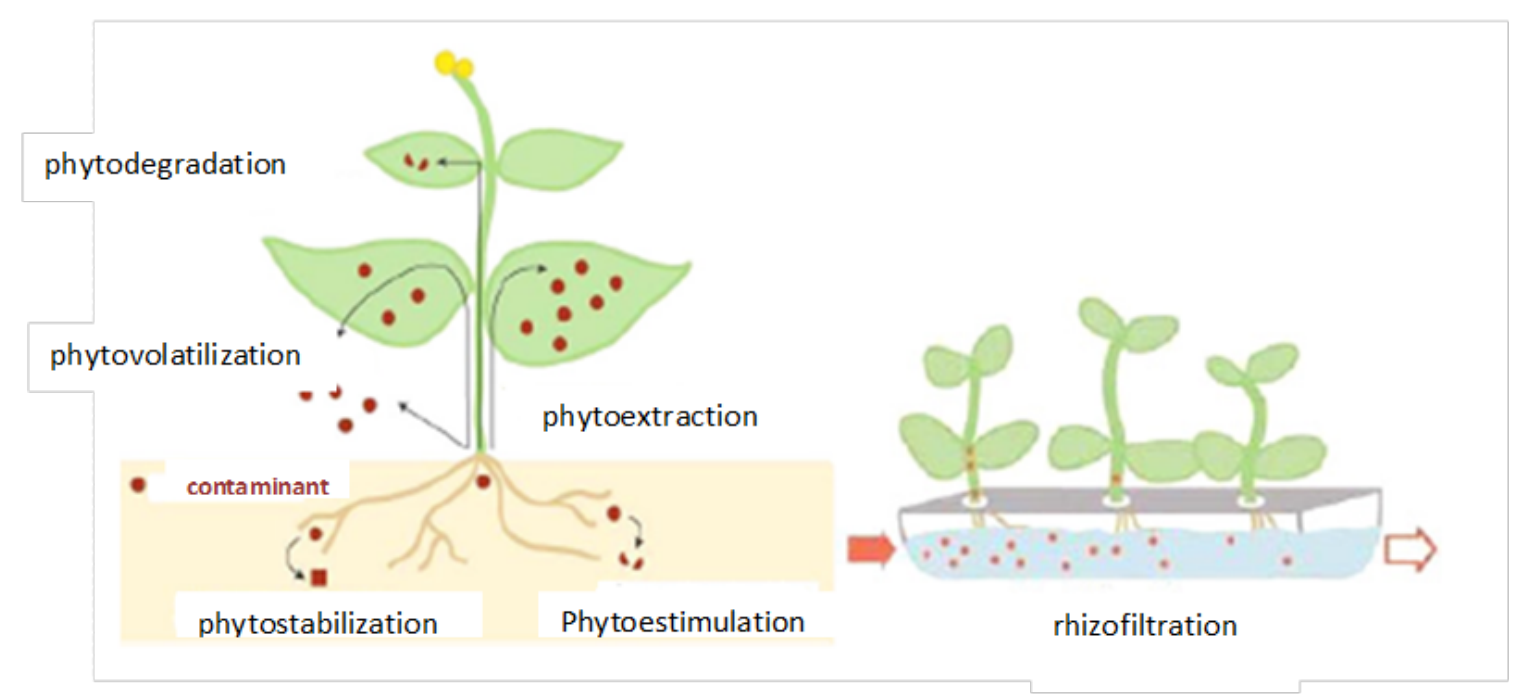

Figure 5 Schematic representation of the different mechanisms of phytoremediation. The contaminant can be stabilized or degraded in the rhizosphere, kidnapped or grading within the plant or volatilized. ${ }^{115}$

Many areas that have presence of metal deposits; they have been covered by metal-tolerant plants, such as in mining areas or mining deposits; they can also be a source of plants that may have a potential use in phytoremediation techniques. In these environments, the plant diversity and the presence of metal tolerant genes is often low; but stress from pollution, encourages and facilitates the selection of tolerant populations versus non-tolerant within the same species. ${ }^{123,124,125}$ Numerous authors analyzed the patterns of accumulation of metals in plants capable of growing in mining areas with high contents of metals, indicating possible use in phytoremediation processes. ${ }^{90,126-133}$ The amount of Hyperaccumulator species is scarce; but there is a significant number of "hypertolerant" species to high levels of metals, this increases the prospects of success for use in the process of phytoremediation of contaminated soils.

Finally, existing ornamental plants in urban areas also constitute a potential source of useful species in phytoremediation processes. It has been found, for example, Nerium oleander leaves that are present in urban areas of Portugal, they have accumulated more than $78 \mathrm{mg} \mathrm{kg}^{-1} \mathrm{~Pb}$ dry weight. ${ }^{126}$ Another plant in which it is found that can accumulate high amounts of $\mathrm{Pb}$ is Canna $x$ generalis, in these conditions this plant is able to produce a lot of biomass, and this condition makes it interesting for phytoextraction. ${ }^{134}$ They have also identified geraniums (Pelargonium sp.) as efficient plants in hyperaccumulation; in greenhouse tests, they were able to absorb $\mathrm{Pb}$, $\mathrm{Cd}$ and $\mathrm{Ni}$ to concentrations of $9,2.7$ and $1.9 \%$, respectively, in a relatively short time. ${ }^{135}$

\section{Conclusion}

Phytoremediation is a viable, efficient and useful for cleaning contaminated soil technology. Its effectiveness has been demonstrated with all kinds of xenobiotic contaminants ranging from inorganic to organic molecules. Phytoremediation includes complex interactions, where they are involved the plant, soil and contaminants. The interactions are multiple and are are not clear It is possible to identify the positive effects of the use of plants in the remediation of contaminated soils, but not the mechanisms of phytoremediation, or performance stages where pollutants are absorbed and transformed to its final destination. They can develop three lines of future research involving the interactions of the participants in the mechanisms, stages and phases of phytoremediation. This knowledge allowed proposing solutions to the problems of pollution and the eventual recovery of soils. ${ }^{136-140}$

\section{Acknowledgments}

None.

\section{Conflict of interests}

The author declares that there is no conflict of interest.

\section{References}

1. Kvesitadze G, Gordeziani M, Khatisashvili G, et al. Some aspects of the enzymatic basic of phytoremediation. J Biol Phys Chem. 2001;1:49-57.

2. Sakakibara M, Ohmori Y, Ha NTH, et al. Phytoremediation of heavy metal contaminated water and sediment by Eleocharis acicularis. Clean Soil Air Water. 2011;39(8):735-741.

3. Miya K, Firestone K. Bioremediation and biodegradation. J Environ Qual. 2001;30:1911-1918.

4. López S, Gallegos M, Pérez L, et al. Mecanismos de fitorremediación de suelos contaminados con moléculas orgánicas xenobióticas. Rev Int Contam Ambient. 2005;21(2):91-100.

5. Tiller KG. Heavy metals in soils and their environmental significance. Advances in soil Science. 1989;9:113-141.

6. Paulo JC, Pratas FJ, Varun M, et al. Phytoremediation of Soils Contaminated with Metals and Metalloids at Mining Areas: Potential of Native Flora. Environmental Risk Assessment of Soil Contamination; 2014.

7. Brady NC, Weil RR. The Nature and Properties of Soils. 13th ed. Upper Saddle River, NJ: Prentice-Hall, Inc; 2002. 
8. Pratas J, Favas PJC, Dsouza R, et al. Phytoremedial assessment of flora tolerant to heavy metals in the contaminated soils of an abandoned $\mathrm{Pb}$ mine in Central Portugal. Chemosphere. 2013;90(8):2216-2225.

9. Chehregani A, Malayer B. Removal of Heavy Metals by Native Accumulator Plants. IJAB. 2007;9(3):462-465.

10. Adriano DC. Trace elements in terrestrial environments: Biogeochemistry, Bioavailability and Risks of Metals. 2nd ed. Springer-Verlag New York, Berlin Heidelberg; 2001

11. Rubio C, González Weller D, Martín-Izquierdo RE, et al. El zinc: oligoelemento esencial. Nutrición Hospitalaria. 2007;22(1):101-107.

12. Adams A, Raman A, Hodgkins D. How do the plants used in phytoremediation in constructed wetlands, a sustainable remediation strategy, perform in heavy-metal contaminated mine sites. Water and Environment Journal. 2013;27(3):373-386.

13. Ross SM. Sources and forms of potentially toxic metals in soil-plant systems. In: Ross SM, editor. Toxic metals in soil-plant systems. John Wiley \& Sons; Chichester, New York, Brisbane, Toronto, Singapore; 1994. p. 3-25.

14. Gough LP. Understanding our fragile environment, lessons from geochemical studies. USGS Circular 1105, United States Government Printing Office, Washington, DC; 1993.

15. Mitchell RL. Trace elements in soil. In: Bear FE, editor. Chemistry of the soil. Reinhold Publishing Corporation, New York; Chapman and Hall, London; 1964. p. 320-368.

16. Abreu MM, Santos ES, Ferreira M, et al. Cistus salviifolius a promising species for mine wastes remediation. Journal of Geochemical Exploration. 2012;113:86-93.

17. Kabata Pendias A, Pendias H. Trace elements in soils and plants. CRC Press Inc., Boca Raton, Florida; 1992.

18. Laghlimi M, Baghdad B, El Hadi H, et al. Phytoremediation Mechanisms of Heavy Metal Contaminated Soils: A Review. Open Journal of Ecology 2015;5(8):375-388.

19. Nriagu JO. Changing Metal Cycles and Human Health (Dahlem Konferenzen). Springer-Verlag, Berlin; 1984.

20. Reiniger P. Biogeochemistry of trace elements. In: Iskander IK, ed. Proc. 4th Intl. Conf. Berkeley, CA, Univ California, Berkeley, CA; 1997.

21. BOE N 15. Real Decreto 9/2005, de 14 de enero, por el que se establece la relación de actividades potencialmente contaminantes del suelo y los criterios y estándares para la declaración de suelos contaminados. 2005.

22. Van-Camp L, Bujarrabal B, Gentile AR, et al. Reports of the Technical Working Groups Established under the Thematic Strategy for Soil Protection. Office for Official Publications of the European Communities, Luxembourg; 2004. 872 p.

23. Van der Ent A, Baker AJM, Reeves RD, et al. Hyperaccumulator of metal and metalloid trace elements: Facts and fiction. Plant Soil. 2013;362(1-2):319-334.

24. EEA (European Environmental Agency). Europe's Environment: the Dobris Assessment - Chapter 7: Soil. Edited by David Stanners and Philippe Bourdeau; 1995.

25. Nriagu JO. Global metal pollution: Poisoning the biosphere. Environment. 1990;32(7):7-33.

26. Nriagu JO, Pacyna JM. Quantitative assessment of World-wide contamination of air, water and soils with trace metals. Nature. 1988;333(6169):134-139.

27. Koptsik S, Koptsik G, Livantsova S, et al. Heavy metals in soils near the nickel smelter: chemistry, spatial variation, and impacts on plant diversity. Journal of Environmental Monitoring. 2003;5(3):441-450.

28. Legrand P, Tiirme MC, Sauve S, et al. Speciation and bioavailability of trace metals $(\mathrm{Cd}, \mathrm{Cu}, \mathrm{Ni}, \mathrm{Pb}, \mathrm{Zn})$ in the rhizosphere of contaminated soils. In: Huang RM, Gobran GR, editor. Biogeochemistry of Trace Elements in the Rhizosphere. Elsevier BV; 2005. p. 261-299.

29. Orescanin V, Mikelić L, Lovrencić I, et al. Environmental contamination assessment of the surroundings of the ex-ferrochromium smelter Dugi Rat, Croatia. J Environ Sci Health A Tox Hazard Subst Environ Eng. 2006;41(11):2547-2555

30. Carlson C, Adriano DC. Environmental Impacts of Coal Combustion Residues. Journal of Environmental Quality. 1993;22(2):227-247.

31. Anderson MA, Bertsch PM, Zelazny LW. Multicomponent transport through soil subjected to coal pile runoff under steady saturated flow. In: Keefer RF, Sajwan KS, editors. Trace Elements in Coal and Coal Combustion Residues. Lewis Publ, Boca Raton, FL; 1993. p. 137-164.

32. Lorestani B, Cheraghi M, Yousefi N. Phytoremediation potential of native plants growing on a heavy metals contaminated soil of copper mine in Iran. World Acade- my of Science, Engineering and Technology. 2011;53:377-382.

33. Andelman JB, Underhill DW. Health Effects from Hazardous Waste Sites. Lewis Publ, Chelsea, MI; 1990.

34. Suter GW, Luxmoore RJ, Smith ED. Compacted soil barriers at abandoned landfill sites are likely to fail in the long term. Journal of Environmental Quality. 1993;22(2):217-226.

35. Hassani AH, Nouri J, Mehregan I, et al. Phytoremediation of Soils Contaminated with Heavy Metals Resulting. Journal of Environment and Earth Science. 2004;4(19):31-37.

36. Mas A, Azcúe JM. Metales en sistemas biológicos. Promociones y Publicaciones Universitarias, SA LCT-74, Barcelona; 1993.

37. Dsouza R, Varun M, Masih J, et al. Identification of Calotropis procera L. as a potential phytoaccumulator of heavy metals from contaminated soils in Urban North Central India. Journal of Hazardous Materials. 2010;184(1-3):457-464.

38. McGrath SP, Zhao FJ, Lombi E. Phytoremediation of metals, metalloids, and radionuclides. Advances in Agronomy. 2002;75:1-56.

39. Varun M, Dsouza R, Pratas J, et al. Metal contamination of soils and plants associated with the glass industry in North-central India: prospects of phytoremediation. Environmental Science and Pollution Research. 2012;19(1):269-281.

40. Ali H, Khan E, Sajad MA. Phytoremediation of heavy metals - Concepts and applicattions. Chemosphere. 2013;91(7):869-881.

41. Baker DE. Copper: soil, water, plant relationships. Fed Proc. 1974;33(5):1188-1193.

42. Zorrig W, Rabhi M, Ferchichi S, et al. Phytodesalination: a solution for salt-affected soils in arid and semi-arid regions. Journal of Arid Land Studies. 2012;22:299-302.

43. Fonder N, Headley T. The taxonomy of treatment wetlands: A proposed classifica $\square$ tion and nomenclature system. Ecological Engineering. 2013;51:203-211.

44. Favas PJC, Pratas J, Prasad MNV. Accumulation of arsenic by aquatic plants in largescale field conditions: Opportunities for phytoremediation and bioindication. Science of the Total Environment. 2012;433:390-397.

45. Merry RH, Tiller KG, Alston AM. Accumulation of copper, lead and arsenic in some Australian orchard soils. Australian Journal of Soil Research. 1983;21(4):549-561. 
46. Kohsiek LHM, Fraters D, Franken R. The pollution of soils and groundwater in the European Community. In: Donker MH, Eijsackers $\mathrm{H}$, editors. Ecotoxicology of soils organisms. Lewis Publ, Boca Raton, FL; 1994. p. 35-70.

47. McBride MB. Molybdenum, sulfur, and other trace elements in farm soils and forages after sewage sludge application. Communications in Soil Science and Plant Analysis. 2004;35(3-4):517-535.

48. Paz-Ferreiro J, Lu H, Fu1 S, et al. Use of phytoremediation and biochar to remediate heavy metal polluted soils: a review. Solid Earth. 2014;5:6575 .

49. CEC (Commission of the European Communities). Directive 2004/35/ CE of the European Parliament and of the Council of 21 April 2006 on environmental liability with regard to the prevention and remedying of environmental damage. 2006. p. 56-75.

50. Oldeman LR. The global extent of soil degradation. In Greenland DJ, Szaboles T, editors. Soil Resilience and Sustainable Land Use. Wallingford, Commonwealth Agricultural Bureau International 1994.

51. MoAFFA Australia. Serious Salinity Warning Must Be Heeded. Ministry of Agriculture, Fisheries and Forestry, Australia; 1999.

52. MoE Japan. Policies and Programmes. Ministry of the Environment, Government of Japan; 2000.

53. UNDP. Human Development Report 2000. Oxford and New York, Oxford University Press; 2000.

54. Shin-Bom L. South Korea Environmental Report. ABS Consulting, Government Institutes Division, Rockville, Maryland, United States; 1996.

55. NEPC. National Environment Protection Council, Australia; 2001.

56. MoE New Zealand. The State of New Zealand's Environment 1997 Wellington, GP Publications; 1997.

57. UNCCD. The Social and Economic Impact of Desertification in Several Asian Countries: Inventory Study. Geneva, Interim Secretariat of the Convention to Combat Desertification; 1998.

58. MoEF India. National Report on Implementation of the United Nations Convention to Combat Desertification. New Delhi, Ministry of Environment and Forests, Government of India; 2000.

59. Semarnat. Secretaría de Medio Ambiente y Recursos Naturales. Comunicación personal con personal de la Dirección General de Manejo Integral de Contaminantes; 2002.

60. INEGI. Instituto Nacional de Estadistica, Geografia e Informatica Censos económicos, inegi, Mexico; 2000.

61. Mosler C. Situación actual de los residuos peligrosos. In: Cortinas C, Mosler C, editors. 2002.

62. PROFEPA. Procuraduría Federal de Protección al Ambiente. Informe annual; 2002. p. 1-118.

63. Volke ST, Velasco TJ. Tecnologías de remediación para suelos contaminados. México DF, DF, Mèxico: Instituto Nacional de Ecología (INE-SEMARNAT); 2002.

64. He ZL, Zhou QX, Xie ZM. Chemical equilibrium of beneficial and pollution elements in soil. Chinese Environmental Science Press, Beijing; 1998.

65. García G, Zanuzzi AL, Faz A. Evaluation of heavy metal availability prior to an in situ soil phytoremediation program. Biodegradation. 2005;16(2):187-194.

66. Prieto J, González CA, Román AD, et al. Plant contamination and phytotoxicity due to heavy metals from soil and water. Tropical and
Subtropical Agroecosystems. 2009;10(1):29-44.

67. Shuman LM. Chemical Forms of Micronutrients in Soils. In: Mortvedt JJ, editor. Micronutrients in Agriculture. SSSA, Madison, WI; 1991.

68. Prieto J, Rubio H, Prieto F. Soil Quality in Terms of Pyhsical-ChemicalMetal Properties for Barely (Hordeum vulgare) Produccion in the State of Hidalgo, Mexico. American-Eurasian J Agric \& Environ Sci. 2011;10(2):230-237.

69. López Arias M, Grau Corbí JM. Metales pesados, materia orgánica y otros parámetros de la capa superficial de los suelos agrícolas y de pastos de la España Peninsular. Ed. INIA; 2004.

70. Navas A, Lindhorfer H. Geochemical speciation of heavy metals in semiarid soils of the central Ebro Valley (Spain). Environment International. 2003;29(1):61-68.

71. Limón AL (Agosto de 2013). Estabilización de los metales pesados en jales mineros mediante la adición de materia orgánica. Querétaro, México. Recuperado el Enero de; 2016.

72. Evans LJ, Spiers GA, Zhao G. Chemical aspeects of heavy metal solubility with reference to sewage sludge amended soils. International Journal of Environmental Analytical Chemistry. 1995;59(2-4):291-302.

73. Acevedo OA, Prieto J, Vela G, et al. Fe, Al and Si Oxides in white "fragipans" developed on materials of volcanic origin. Revista de la Sociedad Geológica de España. 2011;24(3-4):227-235.

74. Evans LJ. Chemistry of metal retention by soils. Environmental Science \& Thecnology. 1989;23(9):1046-1056.

75. Essington ME. Soil and water chemistry: An integrative approach. CRC Press, Boca Raton, FL; 2004.

76. Bingham FT, Page AL, Mahler RJ, et al. Yield and cadmium accumulation of forage species in relation to cadmium content of sludge-amended soil. Journal of Environmental Quality. 1976;5(1):57-59.

77. McBride MB. Environmental chemistry of soils. Oxford Univ. Assessment of a sequential extraction procedure for perturbed Press, New York; 1994.

78. Kelly M. Mining and the freshwater environment. Elsevier, Essex, United Kingdom; 1988.

79. Mulligan CN, Yong RN, Gibbs BF. Remediation for metal-contaminated soils and groundwater: an evaluation. Engineering Geology. 2001;60(14):193-207.

80. Tüzen M. Determination of trace metals in the River Yesilirmak sediments in Tokat, Turkey using sequential extraction procedure. Microchemical Journal. 2003;74(1):105-110.

81. Campbell PGC. Interactions between trace metals and aquatic organism; A critique of the Free-ion activity model. In: Tessier A, Tunner DR. Metals speciation and bioavailability in aquatic systems. Wiley, New York; 1995. p. 45-102.

82. Parker DR, Pedler JF. Revaluating the free-ion activity model of trace metal availability to higher plants. Plant and Soil. 1997;196(2):223-228.

83. Rauret G. Extraction procedures for the determination of heavy metals in contaminated soil and sediment. Talanta. 1998;46(3):449-455.

84. Gleyzes C, Tellier S, Astruc M. Sequential extraction procedures for the characterisation of the fractionation of elements in industriallycontaminated soils. In: Quevauviller PH, editor. Methodologies in Soil and Sediment Fractionation Studies. Royal Society of Chemistry, Cambridge; 2002. p. 66-104.

85. Kaasalainen M, Yli-Halla M. Use of sequential extraction to assess metal partitioning in soils. Environmental Pollution. 2003;126(2):225-233. 
86. Lebourg A, Sterckeman T, Cielsielki H. et al. Intérêt de différents réactifs d'extraction chimique pour l'évaluation de la biodisponibilité des métaux en traces du sol. Agronomie. 1996;16:201-215.

87. Ministerio de Medio Ambiente-Gabinete de Prensa. El Gobierno aprueba un Real Decreto que establece la relación de actividades potencialmente contaminantes del suelo y los criterios para su declaración". Nota de Prensa Consejo de Ministros; 2005.

88. BOE N 96. Real Decreto de Ley 10/1998, de 21 de abril, de Residuos, por lo que se puede prevenir la producción de residuos, establecer el régimen jurídico de su producción y gestión y fomentar, por este orden, su reducción, su reutilización, reciclado y otras formas de valorización, así como regular los suelos contaminados, con la finalidad de proteger el media ambiente y la salud de las personas. 1998.

89. EPA (Environmental Protection Agency). Road map to understanding innovative technology options for brownfields investigation and cleanup. Office of Solid Waste and Emergency Response, Office of Superfund Remediation and Technology Innovation; 2005.

90. Henriques FS, Fernandes JC. Metal uptake and distribution in rush (Juncus conglomeratus L.) plants growing in pyrites mine tailings at Lousal, Portugal. Science of the Total Environment. 1991;102:253-260.

91. Reddy KR, Admas JF, Richardson C. Potential technologies for remediation of Brownfield. Practice Periodical of Hazardous, Toxic, and Radioactive Waste Management. 1999;3(2):61-68.

92. Margesin R, Schinner F. Efficiency of indigenous and inoculated coldadapted soil microorganisms for biodegradation of diesel oil in Alpine soils. Applied and Environmental Microbiology. 1997;63(7):2660-2664.

93. Margesin R, Zimmerbauer A, Schinner F. Monitoring of bioremediation by soil biological activities. Chemosp-here. 2000;40(4):339-346.

94. Kaplan CW, Kitts CL. Bacterial succession in a petroleum land treatmen unit. Appl Environ Microbiol 2004;70(3):1777-178.

95. Margesin R, Schinner F. Biodegradation and bioremediation of hydrocarbons in extreme environments. Applied and Environmental Microbiology. 2001;56(5-6):650-663.

96. Brooks DM, Pando-V L, Ocmin-P A, et al. Resource separation in a Napo- Amazonian gamebird community. In: Brooks DM, Gonzalez-F $\mathrm{F}$, editors. Biology and conservation of cracids in the new millenium. Miscellaneous Publications of the Houston Museum of Natural Science, Houston, Texas; 2001. p. 213-225.

97. Coulon F, Delille D. Effects of biostimulation on growth of indigenous bacteria in sub-Antarctic soil contaminated with oil hydrocarbons. Oil \& Gas Science and Technology. 2003;58(4):469-479.

98. Yerushalmi L, Rocheleau S, Cimpoia R, et al. Enhanced biodegradation of petroleum hydrocarbons in contaminated soil. Bioremediation Journal. 2003;7(1):37-51.

99. Arujanan M, Yee TJ. Bioremediation: Nature's Way to A cleaner Environment. Malaysia Biotechnology Information Centre (MABIC); 2005 .

100. Van Deuren J, Wang Z, Ledbetter J. Remediation technologies screening matrix and reference Guide. 3rd ed. Technology Innovation Office, EPA; 1997.

101. Eweis JB, Ergas SJ, Chang DP. Bioremediation Principles. McGraw-Hill International Editions. 1998. 296 p.

102. http://www.eco2site.com/informes/lihue.asp

103. Milliarium Aureum SL. disponible y consultado en diciembre 2012. 2004.
104. Miliarium Aureum SL. disponible y consultado en diciembre 2012. 2001.

105. Luo CL, Shen ZG, Li XD. Enhanced phytoextraction of $\mathrm{Cu}, \mathrm{Pb}, \mathrm{Zn}$ and Cd with EDTA and EDDS. Chemosphere. 2005;59(1):1-11.

106. Ow DW. Heavy metal tolerance genes: prospective tools for bioremediation. Resources Conservation and Recycling. 1996;18(14):135-149.

107. Salt DE, Smith RD, Raskin I. Phytoremediation. Ann Rev Plant Mol Biol. 1998;49:643-668.

108. Villaseñor L. Biorremediación. Cuadros comparativos de las técnicas in situ, exsitu y las ventajas y desventajas de la biorremediación. Instituto Tecnológico Superior de Irapuato. 2011. p. 1-7.

109. Quintela-Sabarís C, Ribeiro MM, Poncet B, et al. AFLP analysis of the pseudometallophyte Cistus ladanifer: comparison with cpSSRs and exploratory genome scan to investigate loci associated to soil variables. Plant and Soil. 2012;359(1-2):397-413.

110. Cunningham SD, Ow DW. Promises and prospects of phytoremediation. Plant Physiol. 1996;110:715-719.

111. Jara-Peña E, Gómez J, Montoya H, et al. Capacidad fitorremediadora de cinco especies altoandinas de suelos contaminados con metales pesados. Revista Peruana de Biología. 20147;21(2):145-154.

112. InterCOST. Workshop on Bioremediation. Sorrento, Italy; 2000. p. 15-18.

113. Barceló J, Poschenrieder C. Phytoremediation: principles and perspectives. Contributions to Science. 2003;2(3):333-334.

114. Ghosh M, Singh SP. A review on phytoremediation of heavy metals and utilization of it's by products. Applied Ecology and Environmental Research. 2005;3(1):1-18.

115. Pilon-Smits E. Phytoremediation. Annual Review of Plant Biology. 2005;56:15-39.

116. Shabani N, Sayadi MH. Evaluation of heavy metals accumulation by two emergent macrophytes from the polluted soil: an experimental study. Environmentalist. 2012;32(1):91-98.

117. Brooks DM. Competition and coexistence in Neotropical birds: A latitudinal comparison. Texas A \& M Univ, College Station, Texas; 1998.

118. Maywald F, Weigel HJ. Biochemistry and molecular biology of heavy metal accumulation in higher plants. Landbauforschung Volkenrode. 1997;47:103-126.

119. Maric M, Antonijevic M, Alagic S. The investigation of the possibility for using some wild and cultivated plants as hyperaccumulators of heavy metals from contaminated soil. Environmental Science and Pollution Research. 2013;20(2):1181-1188.

120. Reeves RD, Baker AJM. Metal-accumulating plants. In: Raskin I, Ensley $\mathrm{BD}$, editors. Phytoremediation of toxic metals. Using plants to clean up the environment. New York: Wiley; 2000. p. 193-230.

121. Menezes de Sequeira E, Pinto da Silva AR. Ecology of serpentinized areas of north-east Portugal. In: Roberts BA, Proctor J. editors. The ecology of areas with serpentinized rocks A World view. Kluwer Academic Publishers, Printed in the Netherlands; 1992. p. 169-197.

122. Roberts BA, Proctor J, editors. The ecology of areas with serpentinized rocks A World view. Kluwer Academic Publishers, Printed in the Netherlands; 1992.

123. Baker AJM, Proctor J. The influence of cadmium, copper, lead, and zinc on the distribution and evolution of metallophytes in British Isles. Plant Systematics and Evolution. 1990;173:91-108. 
124. Shu W, Zhao Y, Yang B, et al. Accumulation of heavy metals in four grasses grown on lead and zinc mine tailings. $J$ of Env Sciences. 2004;16(5):730-734.

125. Molitor M, Dechamps C, Gruber W, et al. Thlaspi caerulescens on nonmetalliferous soil in Luxembourg: ecological niche and genetic variation in mineral element composition. New Phytologist. 2005;165(2):503-512.

126. Freitas H, Prasad MNV, Pratas J. Plant community tolerant to trace elements growing on the degraded soils of São Domingos mine in the south east of Portugal: environmental implications. Environmental International. 2004;30(1):65-72.

127. Leita L, Mondini C, De Nobili, et al. Heavy metal content in xylem sap (Vitis vinifera) from mining and smelting areas. Environmental Monitoring and Assessment. 1998;50(2):189-200.

128. Melendo M, Benítez E, Nogales R. Assessment of the feasibility of endogenous Mediterranean species for phytoremediation of leadcontaminated areas. Fresenius Environmetal Bulletin. 2002;11:11051109.

129. Flores-Tavizón E, Alarcón-Herrera MT, González-Elizond S, et al. Arsenic tolerating plants from mine sites and hot springs in the semi-arid Region of Chihuahua, Mexico. Acta Biotechnologica. 2003;23:113-119.

130. Alvarenga CJS, Santos RV, Dantas EL. C-O-Sr isotopic stratigraphy of cap carbonates overlying Marinoanage glacial diamictites in the Paraguay Bet, Brazil. Precambrian Research. 2004;131:1-21.

131. Conesa HM, Faz A, Arnaldos R. Heavy metals accumulation and tolerance in plants from mine tailings of the semiarid Cartagena-La Unión mining district (SE Spain). Science of the Total Environment. 2006;366(1):1-11.

132. Alvarez M, Quezada C, Navarro C, et al. An increased expression of nucleolin is associated with a physiological nucleolar segregation. Biochem Biophys Res Commun. 2003;301(1 ):152-158
133. Torres OUB, Ayuso ICA, Gonzalez RV. Disparidades en eficiencia tecnica y convergencia en eficiencia en Mexico: un analisis de frontera. Quivera, 2007;9(2):131-154.

134. Trampczynska A, Gawronski SW, Kutrys S. Canna x generalis as a plant for phytoextraction of heavy metals in urbanized area. Zeszyty Naukowe Politechniki Slaskiej, 2001;45:71-74.

135. Ochonogor RO, Harrison I. Phytoremediation of Heavy Metal Contaminated Soil by Psoralea Pinnata. International Journal of Environmental Science and Development. 2014;5(5):440-443.

136. Alvarenga CJS, Santos RV, Dantas EL. Effects of different light levels on the initial growth and photosynthesis of Croton urucurana Baill. in southeastern Brazil. Revista Árvore, 2003;.27(1):53-57.

137. Basta NT, Ryan JA, Chaney RL. Trace Element Chemistry in ResidualTreated Soil: Key Concepts and Metal Bioavailability. Journal of Environmental Quality. 2005;34(1): 49-63.

138. Diez FJ. Evaluación de plantas tolerantes y optimización del proceso de fitorremediación mediante prácticas agronómicas. Tesis Doctoral. Departamento de Edafoloxía e Química Agrícola. Universidad de Santiago de Compostela, Galicia, España; 2008.

139. Galán E, Gómez Ariza JL, González I. et al. Utilidad de las técnicas de extracción secuencia,l en la mejora y caracterización mineralógica por DRX de suelos y sedimentos con altos contenidos de óxidos de hierro. In: Pascual J, Zapatero J, editors. Integración de Ciencia y Tecnología de Arcillas en el Contexto Tecnológico-Social del Nuevo Milenio. Sociedad Española de Arcillas y Diputación Provincial de Málaga; 2000. p. $337-347$.

140. Margesin R, Zimmerbauer A, Schinner F. Monitoring of bioremediation by soil biological activities. Chemosp-here. 2000;(4) 40:339-346. 